Metode Portofolio Sebagai Upaya....(Adrianus Dedy)

\title{
METODE PORTOFOLIO SEBAGAI UPAYA MENINGKATKAN PEMAHAMAN MAHASISWA TENTANG PARADIGMA BARU PKn SD
}

\author{
Oleh: Adrianus Dedy ${ }^{1}$, Imelda Ratih Ayu ${ }^{2}$ \\ (Dosen Universitas PGRI Palembang) \\ Email: adrianusdedy@univpgri-palembang.ac.id
}

\begin{abstract}
Abstrak
Penelitian ini bertujuan untuk mengetahui apakah terdapat peningkatan pemahaman mahasiswa tentang paradigma baru PKn SD melalui metode perkuliahan berbasis portofolio. Penelitian menggunakan metode penelitian tindakan terhadap mahasiswa dalam proses perkuliahan di kelas, pemahaman direfleksikan dari respon mahasiswa yang didesain subjek penelitian. Penelitian dilakukan dalam tujuh siklus, yang terdiri dari diskusi (brainstroming), mendesain pelaksanaan metode portofolio,eksekusi, dan refleksi akhir. Hasil penelitian menunjukkan 1) metode berbasis portofolio merupakan sesi yang penting dalam project based learning untuk meningkatkan pemahaman mahasiswa, 2) setelah implementasi metode berbasis portofolio, pemahaman mahasiswa tentang paradigma baru PKn SD berada pada level transformasi. Penelitian merekomendasikan agar metode berbasis portofolio dapat diterapkan dalam proses perkuliahan untuk mata kuliah PKn SD
\end{abstract}

Kata Kunci: Portofolio, Paradigma, PKn.

\section{PORTFOLIO METHOD AS AN EFFORT to INCREASE STUDENT UNDERSTANDING OF NEW PARADIGM OF CIVIC EDUCATION AT ELEMENTARY SCHOOL}

\begin{abstract}
This research aims to determine if there is an increase in students' understanding of the new paradigm of civic education (PKn) in Elementary School through a portfolio based lecture method. Research using methods of action research on students in the classroom process, understanding is reflected from student responses designed subject to research. Research is conducted in seven cycles, consisting of a discussion (brainstroming), designing the implementation of portfolio methods, execution, and final reflection. The results showed 1) portfolio-based methods are an important session in project based learning to increase students' understanding, 2) after the implementation of portfolio-based methods, students ' understanding of the new paradigm of civic education in elementary school, stay at the level of transformation. Research recommends that portfolio-based methods can be applied in coursework for civic education courses.
\end{abstract}


Keywords: Academic Procrastination, Group Guidance Services, Discovery Learning

\section{A. PENDAHULUAN}

Pada tahun 2000, setelah Indonesia masuk dalam era reformasi, maka bidang pendidikan pun mengalami perubahan. Perubahan itu terjadi karena adanya tuntutan bahwa sikap, pengetahuan, dan keterampilan yang didapatkan di Sekolah Dasar (SD) harus dapat menopang kebutuhan skill peserta didik untuk menjawabi situasi kekinian. Berdasarkan kenyataan di atas, Pendidikan Kewarganegaraan (PKn) sebagai salah satu mata pelajaran wajib di Sekolah Dasar juga turut larut dalam perubahan.

Sebagai contoh, pada tahun 2004 kurikulum PKn SD diintegrasikan dengan mata pelajaran IPS, menjadi PKPS (Pendidikan Kewarganegaraan dan Pengetahuan Sosial). Pada tahun 2006, adanya perubahan kurikulum KTSP (Kurikulum Tingkat Satuan Pendidikan), PKn tidak lagi terintegrasi dengan mata pelajaran IPS, melainkan berdiri sendiri menjadi mata pelajaran PKN dan diteruskan sampai dengan Kurikulum 2013.

Dalam perspektif Fathurrohman \& Wuryandari (2011:10) diungkapkan bahwa Pendidikan Kewarganegaraan (PKn) yang diajarkan di Sekolah Dasar sesuai tuntutan Kurikulum yang baru (KTSP dan K-13) beresensikan paradigma baru. Paradigma berarti suatu model atau kerangka berpikir yang digunakan dalam proses pendidikan kewarganegaraan di Indonesia. Proses pendidikan tersebut sejalan dengan dinamika perkembangan kehidupan berbangsa dan bernegara yang telah memasuki era reformasi di mana lebih terfokuskan dalam menata kehidupan masyarakat yang lebih demokratis.

Pada hakekatnya, proses pembentukan karakter bangsa diharapkan mengarah pada penciptaan suatu masyarakat Indonesia yang menempatkan demokrasi sebagai titik sentral dalam kehidupan berbangsa dan bernegara. Tugas PKn paradigma baru tersebut adalah mengembangkan pendidikan demokrasi dengan 3 (tiga) fungsi pokok, yakni mengembangkan kecerdasan warga negara (civic intelligence), membina tanggung jawab warga negara (civic responsibility), dan mendorong partisipasi warga negara (civic participation). 
Untuk mengembangkan kehidupan masyarakat yang demokratis melalui Pendidikan Kewarganegaraan (PKn), maka dibutuhkan suatu strategi perkuliahan khusus yang sesuai dengan paradigma baru PKN. Strategi yang dikedepankan adalah metode perkuliahan berbasis portofolio. Hal ini berdasarkan studi/kajian yang dilakukan Depdiknas (2003) yang menekankan bahwa keunggulan metode ini terletak pada pemfokusan perkuliahan yang mengarahkan mahasiswa belajar secara aktif (active learning) dan mampu memecahkan masalah. Karakteristik metode portofolio ini adalah melatih mahasiswa berpikir kritis, berpikir sesuai dengan metode ilmiah, dan mampu memecahkan masalah.

\section{B. METODOLOGI PENELITIAN}

Metode yang digunakan dalam penelitian ialah penelitian tindakan dimana peneliti yang juga sebagai dosen dapat terlibat secara langsung dalam meningkatkan kualitas perkuliahan yang tercermin dalam peningkatan pemahaman mahasiswa. Senada dengan pendapat yang dikemukakan oleh Creswell (2012:592) bahwa tujuan dari penelitian tindakan adalah untuk meningkatkan praktek pendidikan dimana peneliti mempelajari masalah mereka sendiri atau masalah di lingkungan pendidikan. Selanjutnya peneliti terlibat dalam refleksi tentang masalah, mengumpulkan dan menganalisis data, dan menerapkan perubahan atau sebuah rencana tindakan berdasarkan hasil refleksi. Penelitian dilakukan dalam 7 (tujuh) siklus yang terdiri dari brainstorming, proses pelaksanaan metode portofolio, dan refleksi akhir.

\section{HASIL PENELITIAN DAN PEMBAHASAN}

Hasil penelitian diperoleh berdasarkan refleksi pada setiap sesi pelaksanaan metode berbasis portofolio, dan refleksi secara keseluruhan akan proses yang telah dilakukan. Secara rinci hasil penelitian ialah sebagai berikut.

\section{a. Hasil Brainstorming}

Pelaksanaan brainstorming bertujuan untuk memahami pemahaman mahasiswa tentang paradigma baru PKn SD berdasarkan perpektif awal 
mahasiswa, serta hambatan yang ditemui dalam proses pemahaman tersebut, sehingga dapat digali dan ditemui terobosan baru (ide baru) metode terbaru dalam meningkatkan level pemahaman yang lebih utuh dan komprehensif. Hasil brainstorming tersebut disajikan pada tabel 1 di bawah ini.

Tabel 1 Hasil Brainstorming

\begin{tabular}{|c|c|}
\hline Pembahasan & Tanggapan Subjek \\
\hline $\begin{array}{l}\text { Fungsi metode berbasis } \\
\text { portofolio dalam } \\
\text { perkuliahan mata } \\
\text { kuliah Pengembangan } \\
\text { PKn SD }\end{array}$ & $\begin{array}{l}\text { 1. Penyampaian materi perkuliahan melalui metode } \\
\text { berbasis portofolio dapat lebih mudah dipahami } \\
\text { oleh mahasiswa. } \\
\text { 2. Dengan metode berbasis portofolio, mahasiswa } \\
\text { dapat memahami informasi-informasi yang utuh } \\
\text { dan komprehensif tentang isu-isu kebijakan } \\
\text { publik tentang pelaksanaan demokrasi. }\end{array}$ \\
\hline $\begin{array}{l}\text { Hambatan dalam } \\
\text { melaksanakan metode } \\
\text { berbasis portofolio } \\
\text { perkuliahan }\end{array}$ & $\begin{array}{l}\text { Kesulitan yang dihadapi adalah dalam menggunakan } \\
\text { metode perkuliahan berbasis portofolio ialah metode } \\
\text { tersebut hanya menyentuh pemahaman mahasiswa } \\
\text { pada taraf mengerjakan tugas kemudian } \\
\text { dipresentasikan tanpa menemukan dokumen yang } \\
\text { lengkap menyangkut realitas lapangan, selain itu sulit } \\
\text { dalam menemukan topik permasalahan yang menarik } \\
\text { menyangkut isu-isu kebijakan publik (demokrasi) } \\
\text { kekinian }\end{array}$ \\
\hline
\end{tabular}

Berdasarkan sesi brainstorming, pada dasarnya subjek penelitian menyadari pentingnya memanfaatkan metode perkuliahan berbasis portofolio, namun mereka merasa kesulitan untuk menemukan cara yang tepat untuk lebih meningkatkan pemahaman mereka tentang paradigma baru PKn SD dalam mata kuliah Pengembangan PKn SD. Oleh karena itu, butuh pengembangan kreativitas terbaru melalui metode berbasis portofolio dalam proses perkuliahan mata kuliah Pengembangan PKn SD. 
Metode Portofolio Sebagai Upaya....(Adrianus Dedy)

\section{b. Merancang Metode Perkuliahan}

Sesi merancang metode perkuliahan dilakukan dalam 2 (dua) siklus penelitian. Siklus pertama berfokus pada pemilihan metode, dan siklus kedua berfokus pada penentuan topik awal permasalahan.

Kegiatan di siklus pertama, dosen bersama subjek penelitian saling berdiskusi dan membuat perbandingan terhadap setiap metode perkuliahan yang telah diterapkan pada perkuliahan-perkuliahan sebelumnya. Hasil dari brainstorming menunjukkan bahwa metode perkuliahan berbasis portofolio dianggap cocok diterapkan pada proses perkuliahan mata kuliah pengembangan PKn SD.

Kegiatan di siklus selanjutnya dilakukan kembali dengan brainstorming, sehubungan dengan hasil siklus sebelumnya yaitu dosen bersama subjek penelitian mengalami kesuliltan dalam menentukan topik permasalahan yang urgen tentang penataan kehidupan bernegara yang lebih demokratis. Peneliti bersama subjek kembali berdiskusi mengenai permasalahan yang marak terjadi dalam pelaksanaan Pemilu Presiden dan Wakil Presiden dan Legislatif 2019, kekhawatiran masing masing subjek (mahasiswa), dan simpulan informasi yang dibutuhkan. Hasilnya ialah untuk topik pertama yang akan dibahas ialah permasalahan menyangkut angka meninggalnya anggota KPPS yang begitu banyak, dan informasi yang disampaikan berfokus pada dokumen-dokumen yang berkembang dalam media massa dan media sosial.

\section{c. Pelaksanaan Metode Berbasis Portofolio}

Pelaksanaan metode portofolio dilakukan secara bertahap, dan diperoleh 3 siklus penelitian. Dimana subyek penelitian dibagi dalam 4 (kelompok kerja) untuk melakukan pengumpulan dokumen-dokumen menyangkut permasalahan anggota KPPS yang meninggal dunia. Hasil dari pengumpulan dokumendokumen tersebut dipresentasikan di kelas dalam 3 (empat) siklus/pertemuan. Perubahan siklus didasari oleh perubahan level pemahaman subyek yang diharapkan. 
Siklus pertama ialah masing-masing kelompok mempresentasikan hasil pengumpulan dokumen-dokumen. Kelompok 1 mempresentasikan tentang masalah seputar meninggalnya anggota KPPS (berapa jumlah yang meninggal, dan waktu meninggalnya). Kelompok 2 mempresentasikan tentang penilaian kebijakan alternatif yang disarankan untuk menyelesaikan masalah. Kelompok 3 mempresentasikan tentang usulan-usulan kebijakan publik untuk mengatasi masalah. Kelompok 4 mempresentasikan tentang pembuatan rencana tindakan.

Refleksi dari siklus pertama ialah hasil presentasi dari masing-masing kelompok menunjukan minimnya dokumen-dokumen yang dikumpulkan. Dalam arti dokumen-dokumen yang dikumpulkan tersebut cuma mengambil referensinya dari internet dan yang berkembang di media sosial. Tambahan dokumen-dokumen yang dikumpulkan itu kurang menggambarkan pemetaan masalah di wilayah Indonesia secara keseluruhan. Untuk itu butuh kreativitas pemahaman baru dengan memperluas referensi dokumen dan mencakup pemetaan masalah di seluruh wilayah Indonesia.

Siklus dua menguji kembali langkah-langkah metode portofolio dengan perbaikan di siklus sebelumnya. Masing-masing kelompok mempresentasikan hasil pengumpulan dokumen-dokumen seperti pada siklus pertama. Hasil siklus dua menunjukkan bahwa mahasiswa telah mengalami pemahaman tentang permasalahan menyangkut meninggalnya anggota KPPS karena mengalami perluasan referensi dokumen dan keluasan pemetaan permasalahan yang mencakup wilayah di seluruh Indonesia.

Refleksi dari siklus kedua ialah pada dasarnya subjek sudah mengalami peningkatan pemahaman karena mengalami perluasan referensi dan keluasan pemetaan masalah. Namun yang masih menjadi permasalahan adalah belum ada kaitan atau kesinambungan dari masing-masing langkah. Oleh karena itu pada siklus selanjutnya dibuat kesinambungan pemahaman antar langkah, dimana hasil dokumen kelompok 1 menjadi dasar olahan analisis kelompok-kelompok berikutnya sehingga terjadinya satu kesatuan pemahaman yang utuh dan komprehensif 
Siklus ketiga, subjek penelitian secara kreatif dan kritis berusaha membuat pertalian antar langkah-langkah dengan menggunakan pola yang diperoleh di siklus sebelumnya. Hasil siklus ketiga menunjukkan bahwa subjek mengalami peningkatan pemahaman yang signifikan, dimana mahasiswa mampu membuat pertalian antar langkah dengan olahan bahan yang lebih analitif-kritis. Berdasarkan hasil siklus ketiga kegiatan metode berbasis portofolio diakhiri.

\section{d. Refleksi akhir}

Pada refleksi akhir dilakukan analisis terhadap perubahan yang dialami dari sejak proses brainstorming hingga tiga siklus pelaksanaan metode berbasis portofolio. Perubahan cara berpikir dalam setiap siklus dengan mengalami perluasan referensi, keluasan pemetaan masalah, dan pertalian antar langkah menjadi acuan untuk menentukan level pemahaman subjek.

Hasil dari refleksi akhir ialah sebagai berikut.

1. Selama mengikuti sesi mulai dari brainstorming sampai dengan pelaksanaan metode portofolio dalam 3 (tiga) siklus, peneliti dan subyek penelitian berusaha belajar menggunakan metode berbasis portolio lewat proses secara bertahap, runut, dan sistematis disertai dengan kreativitas untuk mencari pemahaman yang lebih tepat dari setiap langkah yang ditempuh.

2. Peneliti dan subyek penelitian mengalami bahwa ada pemahaman yang terus berkembang/meningkat dari setiap sesi/langkah yang ditempuh dan digeluti. Pemahaman yang diperoleh tersebut secara tidak langsung tercermin dari usaha untuk menciptakan perluasan referensi dokumen, kelauasan pemetaan masalah yang terjadi, dan pertalian antar langkah sehingga menemukan makna dari permasalahan yang terjadi.

3. Selama kegiatan berjalan, peneliti dan subyek penelitian dapat berinteraksi melalui metode portofolio dan berdiskusi topik permasalahan yang diangkat mengenai isu terhangat tentang demokratisasi (Pemilu), mengetahui tentang masalah apa saja, penilaian kebijakan alternatif untuk mengatasi masalah, usulan kebijakan publik untuk mengatasi masalah, serta rencana tindakan 
Wahana Didaktika Vol. 17 No.3 September 2019 : 305-314

untuk mengatasi masalah. Rangkaian pemahaman yang meningkat tersebut mencerminkan mahasiswa telah mampu mengembangkan kecerdasan warga negara (civic intelligence), membina tanggung jawab warga negara (civic responsibility), dan mendorong partisipasi warga negara (civic participation) dalam mengatasi persoalan demokratisasi.

\section{PEMBAHASAN}

Berdasarkan hasil refleksi akhir dapat disimpulkan bahwa pemahaman subjek mengalami peningkatan selama kegiatan perkuliahan dengan berbasis pada metode portofolio. Di tahap awal pemahaman subjek masih berada pada level imitasi, yaitu mencoba membuat sesuatu yang belum pernah dilakukan, namun dibantu oleh dokumen-dokumen seadanya, selanjutnya subjek membuat variasi lain yaitu dengan memperluas referensi dokumen dan keluasan cakupan pemetaan masalah, dan diakhir subjek mampu membuat pertalian dan kesinambungan antar langkah, sehingga level pemahaman yang dimiliki subjek mengalami transformasi.

Makna level transformasi pada hasil penelitian yaitu peneliti dan subjek mampu memecahkan masalah yang terjadi dengan memberikan warna baru perihal keluasan referensi dokumen, perluasan cakupan pemetaan masalah, dan kesinambungan antar langkah. Pemahaman dan cara berpikir baru tentang paradigma PKn SD ini sangatlah penting bagi mahasiswa (calon guru SD) dalam memberikan pemahaman peserta didik SD kelak.

Penelitian ini pada hakikatnya sebagai upaya untuk mempersiapkan pendidikan bagi calon guru SD agar mampu memberikan pemahaman baru tentang materi Paradigma baru PKn bagi anak SD. Hal tersebut sejalan dengan pendapat Drucker (1995:67) bahwa manajemen pendidikan dasar terarah pada inovasi yang bercirikan dimensi kreatif (creative process), perubahan (change), serta pembaharuan (new condition). Peningkatan pemahaman melalui metode berbasis portofolio pada dasarnya menstimulasi mahasiswa untuk peka, dan mampu beradaptasi dengan perkembangan peserta didik ke depannya. Sejalan 
dengan pendapat Seligman yang menyatakan bahwa adaptif merupakan komponen penting dalam kreativitas. Dalam arti kreativitas dalam menemukan pemahaman baru bagi peserta didik.

Kunci dari keberhasilan dalam meningkatkan pemahaman ialah intensitas dari brainstorming atau bertukar pikiran untuk menemukan cara baru. Fungsi brainstorming dalam peningkatan pemahaman ialah sebagai proses inkubasi. Inkubasi dalam peningkatan pemahaman bertujuan untuk memunculkan suatu pemahaman serta kematangan terhadap ide yang timbul.

Refleksi secara keseluruhan untuk sesi yang telah dilakukan menunjukkan bahwa metode berbasis portofolio dapat diterapkan dalam mata kuliah pengembangan PKn SD karena dapat membuka pemahaman mahasiswa tentang mengembangkan kecerdasan warga negara (civic intelligence), membina tanggung jawab warga negara (civic responsibility), dan mendorong partisipasi warga negara (civic participation).

Metode berbasis portofolio membantu mahasiswa untuk meningkatkan kreativitas berfikir, kemampuan pemecahan masalah, dan interaksi antara mahasiswa dengan kawan sebayanya untuk menciptakan dan menggunakan pengetahuan baru (Asan \& Haliloglu, 2005). Metode berbasis portofolio memberikan ruang gerak bagi mahasiswa dalam berkreasi dan melakukan kerja proyek dalam upaya menemukan informasi-informasi baru dari berbagai sumber informasi.

\section{SIMPULAN}

Hasil penelitian menunjukkan bahwa metode berbasis porofolio mampu meningkatkan pemahaman mahasiswa tentang paradigma baru PKn SD, yaitu pada level transformasi. Brainstroming merupakan sesi yang paling penting dalam metode berbasis portofolio.

Berdasarkan hasil penelitian direkomendasikan bahwa metode berbasis portofolio dapat diterapkan kembali sebagai metode perkuliahan pada mata kuliah Pengembangan PKn SD bagi mahasiswa semester VI. 


\section{DAFTAR PUSTAKA}

Asan, A \& Haliloglu, Z. (2005). Implementing Project Based Learning In Computer Classroom. The Turkish Online Journal of Educational Technology-TOJET, (online), 4(2): 1-12, (http://www.tojet.net/articles/4310.doc, download at: 30 Maret 2017).

Creswell, J. W. (2012). Educational research: Planning, conducting, and evaluating quantitative and qualitative research. Boston: Pearson.

Depdiknas. 2003. Alur Pikir Pengembangan Kurikulum S-1 PGSD. Jakarta: Dit.Ketenagaan Ditjen Dikti

Drucker, Peter. 1995. Managing In a Time of Great Change. California: First Published

Fathurrohman \& Wuryandani, Wuri. 2011. Pembelajaran PKN Di Sekolah Dasar. Yogyakarta: Nuha Litera 